\title{
Body mass index predicts insulin sensitivity during cardiac surgery: a prospective observational study
}

\section{L'indice de masse corporelle prédit la sensibilité à l'insuline au cours de la chirurgie cardiaque : étude observationnelle prospective}

\author{
Yosuke Nakadate, MD, PhD • Hiroaki Sato, MD, PhD - Tamaki Sato, MD • \\ Takumi Codere-Maruyama, MD, MSc • Takashi Matsukawa, MD, PhD • \\ Thomas Schricker, MD, PhD
}

Received: 19 September 2017/Revised: 28 December 2017/Accepted: 30 December 2017/Published online: 12 February 2018

(C) Canadian Anesthesiologists' Society 2018

\begin{abstract}
Purpose Taking into account the previously described link between body weight and diabetes mellitus (DM) in nonsurgical patients, and the understanding that the degree of intraoperative insulin resistance is a predictor of adverse clinical outcomes, we investigated the relationship between body mass index (BMI) and insulin sensitivity during cardiac surgery.

Methods We prospectively enrolled 400 patients scheduled for elective cardiac surgery and divided them into groups based on the presence or absence of type-2 DM. They were further categorized into four subgroups based on their BMI: group 1- normal weight, BMI 18.5-24.9 $\mathrm{kg} \cdot \mathrm{m}^{-2}$; group 2 overweight, BMI 25-29.9 $\mathrm{kg} \cdot \mathrm{m}^{-2}$; group 3 - obese, BMI 30$34.9 \mathrm{~kg} \cdot \mathrm{m}^{-2} ;$ group 4 - morbidly obese, BMI $\geq 35 \mathrm{~kg} \cdot \mathrm{m}^{-2}$. Insulin sensitivity was assessed using the hyperinsulinemicnormoglycemic clamp technique during surgery. We also analyzed the association of BMI, quality of postoperative glycemic control, and postoperative outcomes.

Results A linear negative relationship between BMI and insulin sensitivity $(r=0.42, P<0.001)$ was observed, independent of the patients' diabetic state. There was also a positive correlation between BMI and postoperative
\end{abstract}

Y. Nakadate, MD, PhD ( $₫) \cdot$ H. Sato, MD, PhD .

T. Sato, MD · T. Codere-Maruyama, MD, MSc .

T. Schricker, MD, PhD

Department of Anesthesia, McGill University Health Centre

Glen Site, Royal Victoria Hospital, 1001 blvd, Decarie,

Montreal, QC H4A 3J1, Canada

e-mail: yosuke.nakadate@mail.mcgill.ca

T. Matsukawa, MD, PhD

Department of Anesthesiology, University of Yamanashi,

Yamanashi, Japan glycemia $(r=0.30, P<0.001)$ though the relationship between BMI and major and infectious complication was not significant $(P=0.56, P=0.10$, respectively).

Conclusions Patient BMI may be used as a simple predictor of insulin sensitivity during cardiac surgery and as a predictor of the quality of postoperative glycemic control. A larger cohort will be necessary to evaluate the association of BMI, perioperative insulin resistance, and clinical outcomes.

\section{Résumé \\ Objectif En tenant compte du lien déjà décrit entre poids corporel et diabète chez des patients non chirurgicaux et la notion que le niveau de résistance peropératoire à l'insuline est un élément prédictif de résultats cliniques défavorables, nous avons étudié le lien entre l'indice de masse corporelle (IMC) et la sensibilité à l'insuline au cours de la chirurgie cardiaque.}

Méthodes Nous avons recruté de façon prospective 400 patients devant subir une chirurgie cardiaque élective et les avons séparés en groupes en fonction de l'existence ou de l'absence d'un diabète de type 2 (DT2). En outre, ils ont été également classés en quatre sous-groupes en fonction de leur IMC: groupe 1 poids normal, IMC : 18,5 à $24,9 \mathrm{~kg} \mathrm{~m}^{-2}$; groupe 2 surcharge pondérale, IMC : 25 à $29,9 \mathrm{~kg} \mathrm{~m}^{-2}$; groupe 3 - obésité, IMC : 30 à 34,9 $\mathrm{kg} \mathrm{m}^{-2}$; groupe 4 - obésité morbide, IMC > $35 \mathrm{~kg} \mathrm{~m}^{-2}$. La sensibilité à l'insuline a été évaluée au moyen de la technique du clamp hyperinsulinémique-normoglycémique au cours de l'intervention. Nous avons également analysé l'association de l'IMC, de la qualité du contrôle glycémique postopératoire et de l'évolution postopératoire. 
Résultats Une relation linéaire négative entre l'IMC et la sensibilité à l'insuline $(r=0,42, P<0,001)$ a été observée, indépendamment $d u$ statut de diabète $d u$ patient. Il y a eu aussi une corrélation positive entre l'IMC et la glycémie postopératoire $(r=0,30, P<0,001)$ bien que les relations entre l'IMC et les complications majeures ou infectieuses n'aient pas été significatives (respectivement, $P=0,56, P=0,10$ ).

Conclusions L'IMC des patients peut être utilisé comme simple facteur prédictif de la sensibilité à l'insuline au cours de la chirurgie cardiaque et comme élément prédictif de la qualité du contrôle glycémique postopératoire. Une plus grande cohorte sera nécessaire pour évaluer l'association entre IMC, résistance à l'insuline périopératoire et l'évolution clinique.

Obesity is associated with insulin resistance and type-2 diabetes mellitus (DM). ${ }^{1}$ Other medical conditions linked with obesity include coronary heart disease, hypertension, and obstructive sleep apnea., ${ }^{2,3}$ Although in the context of surgery the impact of obesity on the cardiovascular and pulmonary system is particularly relevant, ${ }^{2,3}$ it remains unclear whether obesity is an independent risk factor of morbidity and mortality after cardiac surgery. While retrospective studies in the early 1990s reported a weight-dependent increase in mortality ${ }^{4}$ and morbidity, ${ }^{5}$ more recent retrospective and prospective multicenter trials have failed to observe any clinical impact of body weight ${ }^{6,7}$ in patients undergoing coronary artery bypass grafting surgery (CABG).

Taking into account the link between body weight and DM in non-surgical patients ${ }^{8-11}$ and that the degree of insulin resistance is a predictor of adverse events after cardiac surgery, ${ }^{11,12}$ we hypothesized that obesity would be associated with decreased intraoperative insulin sensitivity in cardiac surgical patients. Accordingly, we primarily investigated the relationship between body mass index (BMI) and insulin sensitivity in patients undergoing cardiac surgery. As a secondary aim, we also examined the impact of BMI on the quality of glycemic control and clinical outcomes.

\section{Methods}

With approval from the McGill University Health Centre Research Ethics Board (3 March 2014), we obtained written informed consent from patients scheduled for elective CABG, valve surgery, or a combination of both. Because of different inflammatory, hemodynamic, and metabolic responses, ${ }^{13,14}$ patients undergoing off-pump $\mathrm{CABG}$ or procedures with anticipated deep hypothermic circulatory arrest were excluded. We also excluded patients who were severely underweight $\left(\mathrm{BMI}<18.5 \mathrm{~kg} \cdot \mathrm{m}^{-2}\right.$ ), on hemodialysis, with preoperative troponin I levels $>0.5$ $\mathrm{ng} \cdot \mathrm{L}^{-1}$, and not known to have DM presenting with fasting blood glucose levels $>7.0 \mathrm{mMol} \cdot \mathrm{L}^{-1}\left(126 \mathrm{mg} \cdot \mathrm{dL}^{-1}\right)$ or glycated hemoglobin $\left(\mathrm{HbA}_{1 \mathrm{c}}\right)>6.0 \%$.

\section{Procedures}

Patients were categorized according to the presence or absence of type-2 DM and then divided into four groups based on their BMI. Only patients receiving treatment (i.e., oral antihyperglycemic agents or insulin) were considered diabetic. The groups were identified as:

Group 1 normal weight, BMI 18.5-24.9 $\mathrm{kg} \cdot \mathrm{m}^{-2}$

Group 2 overweight, BMI $25-29.9 \mathrm{~kg} \cdot \mathrm{m}^{-2}$

Group 3 obese, BMI $30-34.9 \mathrm{~kg} \cdot \mathrm{m}^{-2}$

Group 4 morbidly obese, BMI $\geq 35 \mathrm{~kg} \cdot \mathrm{m}^{-2}$

We recorded the patients' age, sex, Parsonnet score, ${ }^{15}$ Euroscore, ${ }^{16}$ medical history, laboratory data $\left(\mathrm{HbA}_{1 \mathrm{c}}\right.$, hematocrit, creatinine), and left ventricular ejection function.

In patients with DM, the administration of oral hypoglycemic drugs was discontinued $24 \mathrm{hr}$ before surgery. The anesthetic care until cardiopulmonary bypass (CPB) was standardized for all patients. Standard anesthesia monitors $^{17}$ were supplemented by central venous or pulmonary artery catheters as well as transesophageal echocardiography. Midazolam, propofol, sufentanil, volatile anesthetics, and a depolarizing or nondepolarizing muscle relaxant were given during induction and maintenance of anesthesia. Epinephrine or norepinephrine (both at $1-10 \mu \mathrm{g} \cdot \mathrm{min}^{-1}$ ) were used as inotropes and vasopressors to maintain a systolic blood pressure $\geq 100 \mathrm{mmHg}$ before and after $\mathrm{CPB}$ and a perfusion pressure between 50-70 $\mathrm{mmHg}$ during CPB. We also recorded the type of surgical procedures, anesthetic and surgical time, and usage of epinephrine and norepinephrine.

Insulin sensitivity was determined by using the hyperinsulinemic-normoglycemic clamp technique as has been previously described. ${ }^{18,19}$ Briefly, this begins before the induction of anesthesia, with insulin (Humulin R; Eli Lilly \& Company, Indianapolis, IN, USA) infused at 5 $\mathrm{mU} \cdot \mathrm{kg}^{-1} \cdot \mathrm{min}^{-1}$ (based on actual body weight) followed by blood glucose measurements every five to ten minutes using the Accu-chek glucose monitor (Roche Diagnostics, Switzerland). This dose of insulin results in supraphysiologic plasma insulin levels, ${ }^{20}$ which are required to assure complete suppression of endogenous 
glucose production, maximum glucose uptake, and utilization by insulin-sensitive tissues.

When the blood glucose was $<6.1 \mathrm{mMol} \cdot \mathrm{L}^{-1}(110$ $\left.\mathrm{mg} \cdot \mathrm{dL}^{-1}\right)$, an infusion of $20 \%$ dextrose supplemented with phosphate $\left(30 \mathrm{mMol} \cdot \mathrm{L}^{-1}\right)$ was started at a rate adjusted to maintain the blood glucose between 4-6 $\mathrm{mMol} \cdot \mathrm{L}^{-1}\left(72-109 \mathrm{mg} \cdot \mathrm{dL}^{-1}\right)$. The dextrose infusion rate during steady-state conditions before CPB was used as an indicator of insulin sensitivity (i.e., with lower indicating poor insulin sensitivity). We assumed steady-state conditions if the coefficient of variation $(\mathrm{CV})$ of five subsequent dextrose infusion rates was less than $5 \%$. Patients who did not obtain a $\mathrm{CV}<5 \%$ (e.g., with $\mathrm{CPB}$ starting before establishment of a steady dextrose infusion rate because of large fluctuations in blood glucose levels) were excluded in the final analysis.

Glycemic control in the intensive care unit (ICU) was as follows. Blood glucose was measured every one to two hours until the target range $\left(4.0-10.0 \mathrm{mMol} \cdot \mathrm{L}^{-1} ; 72-180\right.$ $\mathrm{mg} \cdot \mathrm{dL}^{-1}$ ) was achieved and then every four to six hours thereafter. If the blood glucose was $\geq 10.1 \mathrm{mMol} \cdot \mathrm{L}^{-1}$ $\left(\geq 181 \mathrm{mg} \cdot \mathrm{dL}^{-1}\right.$ ), an insulin infusion of $2 \mathrm{units} \cdot \mathrm{hr}^{-1}$ was started and titrated according to the following sliding scale based on the measured blood glucose:

$\geq \quad 10.1 \mathrm{mMol} \cdot \mathrm{L}^{-1}$ increase insulin infusion by 2 $\left(\geq 181 \mathrm{mg} \cdot \mathrm{dL}^{-1}\right) \quad$ units $\cdot \mathrm{hr}^{-1}$;

8.1-10.0 $\mathrm{mMol} \cdot \mathrm{L}^{-1}$ maintain current insulin $\left(145-180 \mathrm{mg} \cdot \mathrm{dL}^{-1}\right) \quad$ infusion rate;

4.1-8.0 $\mathrm{mMol} \cdot \mathrm{L}^{-1}$ stop insulin infusion;

$\left(73-144 \mathrm{mg} \cdot \mathrm{dL}^{-1}\right)$

$\leq \quad 4.0 \mathrm{mMol} \cdot \mathrm{L}^{-1}$ stop insulin infusion and $\left(\leq 72 \mathrm{mg} \cdot \mathrm{dL}^{-1}\right) \quad$ administer $10 \mathrm{~mL}$ of $20 \%$ dextrose

The mean and median blood glucose during the first 48 postoperative hours was calculated. Major complications included all-cause mortality, myocardial failure (cardiac index $<1.8 \mathrm{~L} \cdot \mathrm{min}^{-1} \cdot \mathrm{m}^{-2}$ and mixed venous saturation $<$ $55 \%$, despite adequate fluid replacement, and high-dose inotropic support requiring intra-aortic balloon pump, right and/or left ventricular assist device, and/or extracorporeal mechanical oxygenation after separation from CPB), stroke (new focal or global neurologic deficit confirmed by clinical findings and computed tomographic scan), dialysis, and major infections (i.e., sepsis, ${ }^{21}$ pneumonia requiring mechanical ventilation and antibiotics, or deep sternal wound infection). Other complications included minor infections (e.g., pneumonia not requiring mechanical ventilation, superficial wound, and urinary tract infection), temporary neurologic dysfunction (delirium, confusion), atrial fibrillation, and blood product transfusions. We also documented the peak postoperative creatinine, troponin, and lactate concentrations, duration of intubation, and length of ICU and hospital stay. Complications were assessed 30 days after surgery. ${ }^{22}$ Complications were $a$ priori defined using the same criteria as in our previously published study. ${ }^{12}$

The primary endpoint of the study was insulin sensitivity during surgery. Secondary endpoints were the average of blood glucose during the first $48 \mathrm{hr}$ after surgery and the incidence of postoperative adverse events.

\section{Statistical analysis}

Sample size was calculated on the basis of mean [standard deviation (SD)] insulin sensitivity levels previously reported $^{12}$ during cardiac surgery $\left[\begin{array}{ll}5.0 & (2.0)\end{array}\right.$ $\mathrm{mg} \cdot \mathrm{kg}^{-1} \cdot \mathrm{min}^{-1}$ in patients without DM, 3.8 (1.6) $\mathrm{mg} \cdot \mathrm{kg}^{-1} \cdot \mathrm{min}^{-1}$ in patients with well-controlled DM $(\mathrm{HbA} 1 \mathrm{c}<6.5 \%)$, and $3.2(1.4) \mathrm{mg} \cdot \mathrm{kg}^{-1} \cdot \mathrm{min}^{-1}$ in poorly controlled diabetics $(\mathrm{HbAl} 1 \mathrm{c}>6.5 \%)$ ] and the assumption of a difference in insulin sensitivity among the four weight groups. A sample size of 351 achieves $90 \%$ power to detect a difference in insulin sensitivity of $0.4 \mathrm{mg} \cdot \mathrm{kg}^{-1} \cdot \mathrm{min}^{-1}$ under the alternative hypothesis with a four-group ratio of 2:4:2:1 (group 1:group 2:group 3:group 4) based on the BMI distribution in cardiac surgery patients, ${ }^{23-25}$ an SD in insulin sensitivity of $1.8 \mathrm{mg} \cdot \mathrm{kg}^{-1} \cdot \mathrm{min}^{-1}$, and an alpha level of 0.05 .

Patient, surgical, and laboratory testing data were summarized using descriptive statistics. Categorical variables were described as counts and percentages. Continuous variables with normal distribution are presented as mean (SD) and variables with skewed distribution are presented as median (interquartile range [IQR]). All data were tested for normality using the Kolmogorov-Smirnov test.

Categorical variables were analyzed by Chi-square test. Where the assumption of normal distribution was confirmed, one-way analysis of variance followed by the Tukey-Kramer post-hoc test or an independent two-sample $t$ test was used. Otherwise, a Kruskal-Wallis test with Steel-Dwass multiple comparisons posttest or a MannWhitney U test was performed.

The Pearson correlation coefficient and linear regression were used to describe the association between BMI and insulin sensitivity and between BMI and postoperative blood glucose. A logistic regression model assessed the relationship between BMI and postoperative complications and also adjusted for potential confounders (i.e, age, gender, DM, and HbA1c). A two-sided $P \leq 0.05$ was considered statistically significant. All statistical analyses were performed using SPSS 21 for Windows (IBM, Chicago, IL, USA) and PASS 11 (NCSS, Kaysville, UT, USA). 


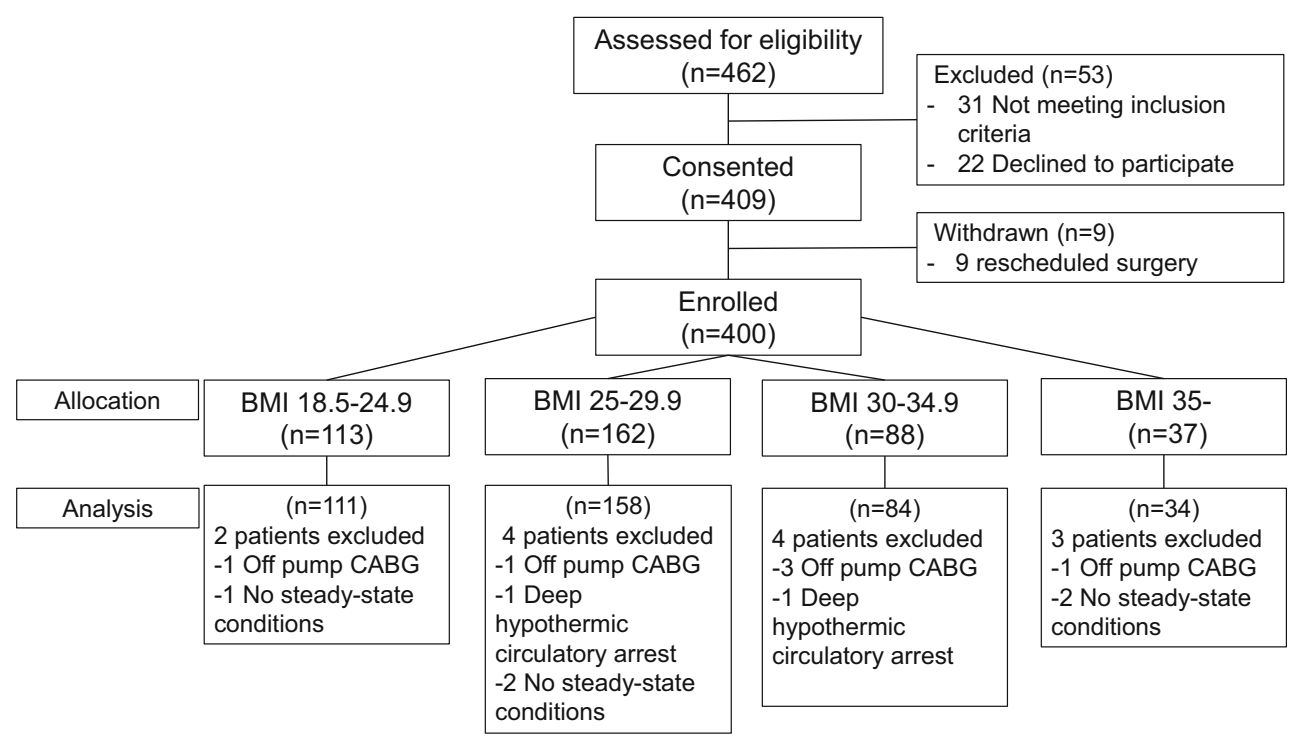

Fig. 1 Patient flow diagram. $\mathrm{BMI}=$ body mass index; $\mathrm{CABG}=$ coronary artery bypass grafting

\section{Results}

We enrolled 400 patients, 140 (35.0\%) of whom had type-2 DM. Thirteen patients were excluded because the procedure was performed off-pump $(n=6)$ or under hypothermic circulatory arrest $(n=2)$ or because steadystate conditions were not established $(n=5)$ (Fig. 1). There were some statistically significant differences between groups in age, sex, HbA1c, and DM (Table 1). Patients in group 1 (normal weight) were older than patients in group 2 (overweight) and group 3 (obese). Group 1 (normal weight) showed a lower rate of DM and group 3 (obese) and group 4 (morbidly obese) showed a higher rate.

Primary and secondary endpoints

For non-diabetic patients, the mean (SD) insulin sensitivity was higher in group 1 [normal weight, 5.6 (1.8) $\mathrm{mg} \cdot \mathrm{kg}^{-1} \cdot \mathrm{min}^{-1}$ ] than in group 2 [overweight, 4.5 (1.4) $\mathrm{mg} \cdot \mathrm{kg}^{-1} \cdot \mathrm{min}^{-1} ;$ mean difference $v s$ group $1,1.1$ $\mathrm{mg} \cdot \mathrm{kg}^{-1} \cdot \mathrm{min}^{-1} ; 95 \% \mathrm{CI}, 0.5$ to $\left.1.7 ; P<0.001\right]$, group 3 [obese, $4.2(1.5) \mathrm{mg} \cdot \mathrm{kg}^{-1} \cdot \mathrm{min}^{-1}$; mean difference $v s$ group $1,1.4 \mathrm{mg} \cdot \mathrm{kg}^{-1} \cdot \mathrm{min}^{-1} ; 95 \% \mathrm{CI}, 0.7$ to $\left.2.1 ; P<0.001\right]$, and group 4 [morbidly obese, $3.5(1.7) \mathrm{mg} \cdot \mathrm{kg}^{-1} \cdot \mathrm{min}^{-1}$; mean difference $v s$ group $1,2.1 \mathrm{mg} \cdot \mathrm{kg}^{-1} \cdot \mathrm{min}^{-1} ; 95 \% \mathrm{CI}, 1.0$ to 3.1; $P<0.001$ ] (Fig. 2a).

For diabetic patients, the mean (SD) insulin sensitivity in group 1 [normal weight, $3.8(1.8) \mathrm{mg} \cdot \mathrm{kg}^{-1} \cdot \mathrm{min}^{-1}$ ] was higher than in group 3 [obese, $2.3(1.4) \mathrm{mg} \cdot \mathrm{kg}^{-1} \cdot \mathrm{min}^{-1}$; mean difference $v s$ group $1,1.4 \mathrm{mg} \cdot \mathrm{kg}^{-1} \cdot \mathrm{min}^{-1} ; 95 \% \mathrm{CI}$, 0.4 to $2.5 ; P<0.001$ ] and in group 4 [morbidly obese, 2.2 (1.3) $\mathrm{mg} \cdot \mathrm{kg}^{-1} \cdot \mathrm{min}^{-1}$; mean difference $v s$ group $1,1.6$ $\mathrm{mg} \cdot \mathrm{kg}^{-1} \cdot \mathrm{min}^{-1} ; 95 \% \mathrm{CI}, 0.3$ to $2.9 ; P=0.002$ ] (Fig. 2a).
The mean (SD) insulin sensitivity in group 2 [overweight, $\left.3.5(1.4) \mathrm{mg} \cdot \mathrm{kg}^{-1} \cdot \mathrm{min}^{-1}\right]$ also was higher than in group 3 [2.3 (1.4) $\mathrm{mg} \cdot \mathrm{kg}^{-1} \cdot \mathrm{min}^{-1}$; mean difference $v$ s group 2, 1.1 $\mathrm{mg} \cdot \mathrm{kg}^{-1} \cdot \mathrm{min}^{-1} ; 95 \% \mathrm{CI}, 0.4$ to $\left.2.5 ; P<0.001\right]$ and group 4 [morbidly obese, 2.2 (1.3) $\mathrm{mg} \cdot \mathrm{kg}^{-1} \cdot \mathrm{min}^{-1} ;$ mean difference $v s$ group 2, $1.3 \mathrm{mg} \cdot \mathrm{kg}^{-1} \cdot \mathrm{min}^{-1} ; 95 \% \mathrm{CI}, 0.1$ to $2.4 ; P=0.04$ ] (Fig. 2a).

On average, patients with DM were less insulin sensitive than patients without DM $\left[3.0\right.$ (1.6) $\mathrm{mg} \cdot \mathrm{kg}^{-1} \cdot \mathrm{min}^{-1}$ vs 4.7 (1.7) $\mathrm{mg} \cdot \mathrm{kg}^{-1} \cdot \mathrm{min}^{-1}$, respectively; mean difference, 1.7 $\mathrm{mg} \cdot \mathrm{kg}^{-1} \cdot \mathrm{min}^{-1} ; 95 \% \mathrm{CI}, 1.4$ to $\left.2.1 ; P<0.001\right]$.

A negative correlation between BMI and insulin sensitivity was observed independent of the presence of diabetes mellitus (Fig. 2b). We also found a positive correlation between BMI and postoperative glycemia (Fig. 3).

The incidence of major complications among the four groups was similar and no significant correlation with BMI was detected (Table 2). After adjusting for age, gender, DM, and HbA1c values, morbidly obese patients had a significantly increased risk of developing an infectious complication (odds ratio, 3.4; 95\% CI, 1.03 to $11.2, P=$ 0.04) (Table 3).

\section{Discussion}

We report a negative correlation between BMI and insulin sensitivity during open heart surgery. While this association was similar in subjects with or without diabetes, patients with diabetes were less insulin sensitive in all BMI groups. We further show a relationship between BMI and postoperative glycemia. 
Table 1 Patient characteristics

\begin{tabular}{|c|c|c|c|c|c|}
\hline & $\begin{array}{l}\text { Normal weight } \\
(n=111)\end{array}$ & $\begin{array}{l}\text { Overweight } \\
(n=158)\end{array}$ & $\begin{array}{l}\text { Obese } \\
(n=84)\end{array}$ & $\begin{array}{l}\text { Morbidly obese } \\
(n=34)\end{array}$ & $P$ value \\
\hline Age-year, mean (SD) & $69(11)$ & $66(10)$ & $64(12)$ & $66(11)$ & 0.01 \\
\hline Female- $n(\%)$ & $28(25)$ & $26(17)$ & $21(25)$ & $13(38)$ & 0.03 \\
\hline Parsonnet score-mean (SD) & $15(11)$ & $13(11)$ & $15(11)$ & $19(10)$ & 0.14 \\
\hline Euro score 1-mean (SD) & $2.8(2.0)$ & $3.0(2.3)$ & $2.9(2.1)$ & $3.0(2.3)$ & 0.95 \\
\hline HbA1c-\%, mean (SD) & $5.9(1.1)$ & $5.8(0.9)$ & $6.4(1.3)$ & $6.2(0.9)$ & 0.01 \\
\hline Diabetes mellitus- $n(\%)$ & $22(20)$ & $54(34)$ & $38(45)$ & $17(50)$ & $<0.001$ \\
\hline Insulin- $n(\%)$ & $7(6)$ & $9(6)$ & $12(14)$ & $10(30)$ & $<0.001$ \\
\hline Thiazolidinediones- $n(\%)$ & $0(0)$ & $4(3)$ & $2(2)$ & $0(0)$ & 0.30 \\
\hline Biguanides- $n(\%)$ & $15(14)$ & $41(26)$ & $25(30)$ & $11(32)$ & 0.02 \\
\hline Sulfonylureas and meglitinides- $n(\%)$ & $2(8)$ & $10(6)$ & $6(7)$ & $6(17)$ & 0.01 \\
\hline Hypertension- $n(\%)$ & $95(86)$ & $127(80)$ & $76(91)$ & $32(94)$ & 0.07 \\
\hline ACE inhibitors- $n(\%)$ & $38(34)$ & $53(34)$ & $33(39)$ & $18(53)$ & 0.17 \\
\hline$\beta$-Blockers- $n(\%)$ & $81(73)$ & $109(69)$ & $58(69)$ & $26(77)$ & 0.76 \\
\hline Ca channel-blockers- $n(\%)$ & $18(16)$ & $32(20)$ & $18(21)$ & $12(35)$ & 0.12 \\
\hline Statin intake- $n(\%)$ & $91(82)$ & $119(75)$ & $61(72)$ & $29(85)$ & 0.26 \\
\hline Smoking history- $n(\%)$ & $26(23)$ & $29(18)$ & $21(25)$ & $6(18)$ & 0.56 \\
\hline CAD- $n(\%)$ & $54(49)$ & $93(59)$ & $41(49)$ & $19(56)$ & 0.30 \\
\hline CHF- $n(\%)$ & $17(15)$ & $22(14)$ & $12(14)$ & $4(12)$ & 0.96 \\
\hline CVD- $n(\%)$ & $1(1)$ & $11(7)$ & $3(4)$ & $1(3)$ & 0.10 \\
\hline PVD- $n(\%)$ & $5(5)$ & $5(3)$ & $3(4)$ & $0(0)$ & 0.65 \\
\hline COPD- $n(\%)$ & $12(11)$ & $23(14)$ & $16(19)$ & $7(11)$ & 0.33 \\
\hline Atrial fibrillation- $n(\%)$ & $8(7)$ & $17(11)$ & $7(8)$ & $3(9)$ & 0.78 \\
\hline Steroid intake- $n(\%)$ & $2(2)$ & $9(6)$ & $2(2)$ & $3(9)$ & 0.17 \\
\hline LVEF-\%, mean (SD) & $51(12)$ & $51(11)$ & $51(12)$ & $50(12)$ & 0.99 \\
\hline Hematocrit-\%, mean (SD) & $39(6)$ & $40(5)$ & $40(5)$ & $39(5)$ & 0.51 \\
\hline Creatinine- $\mu \mathrm{Mol} \mathrm{L}^{-1}$, mean (SD) & $95(41)$ & $94(26)$ & $87(21)$ & $92(24)$ & 0.18 \\
\hline Surgical procedure & & & & & 0.53 \\
\hline CABG- $n(\%)$ & $73(66)$ & $106(67)$ & $51(61)$ & $19(56)$ & \\
\hline Valve- $n(\%)$ & $17(15)$ & $28(18)$ & $20(24)$ & $6(18)$ & \\
\hline CABG and valve- $n(\%)$ & $21(19)$ & $24(15)$ & $13(15)$ & $9(26)$ & \\
\hline Aortic cross clamp time-min, mean (SD) & $86(32)$ & $86(31)$ & $86(31)$ & $89(31)$ & 0.96 \\
\hline CPB time-min, mean (SD) & $104(38)$ & $109(47)$ & $105(38)$ & $115(46)$ & 0.56 \\
\hline Duration of surgery-min, mean (SD) & $213(57)$ & $229(80)$ & $214(64)$ & $239(80)$ & 0.11 \\
\hline Duration of anesthesia-min, mean (SD) & $288(60)$ & $300(75)$ & $289(63)$ & $313(81)$ & 0.56 \\
\hline Epinephrine infusion at the end of operation- $n(\%)$ & $27(24)$ & $30(19)$ & $14(17)$ & $9(27)$ & 0.44 \\
\hline Norepinephrine infusion at the end of operation- $n(\%)$ & $49(44)$ & $57(36)$ & $39(46)$ & $17(50)$ & 0.26 \\
\hline
\end{tabular}

$\mathrm{ACE}=$ angiotensin-converting enzyme; $\mathrm{CABG}=$ coronary artery bypass grafting; $\mathrm{CAD}=$ coronary artery disease CHF $=$ congestive heart failure; $\mathrm{COPD}=$ chronic obstructive pulmonary disease $\mathrm{CPB}=$ cardiopulmonary bypass; $\mathrm{CVD}=$ cerebrovascular disease; HbAlc $=$ glycated hemoglobin; $\mathrm{LVEF}=$ left ventricular ejection fraction; PVD = peripheral vascular disease

Whether BMI is an independent predictor of adverse events in surgical patients is still a matter of controversy. While some studies have reported an increased incidence of complications, ${ }^{4,5,26-28}$ others have failed to observe any impact of body weight on outcome. ${ }^{6,7,29}$ In fact, following cardiac, ${ }^{30}$ vascular, ${ }^{31}$ and general surgery procedures, ${ }^{32}$ obesity is associated with improved outcomes compared with patients with normal body weight, a concept known as the "obesity paradox". ${ }^{33}$ The worst outcomes occurred in the underweight and morbid obesity subjects. Similar observations were made in medical patients with diabetes mellitus, end-stage renal disease, hypertension, heart failure, and coronary artery and peripheral vascular disease. $^{33}$ 
Fig. 2 A) Insulin sensitivity (dextrose infusion $\mathrm{mg} \cdot \mathrm{kg}^{-1} \cdot \mathrm{min}^{-1}$ ) in all patients; B) in patients without DM and C) with DM. Data are expressed as mean (SD). $* P<0.05 v s$ group $1 ; \uparrow P<0.05$ vs group 2 . Relationship between BMI $\left(\mathrm{kg} \cdot \mathrm{m}^{-2}\right)$ and insulin sensitivity (dextrose infusion, $\mathrm{mg} \cdot \mathrm{kg}^{-1} \cdot \mathrm{min}^{-1}$ ) in all patients A) insulin sensitivity $=-0.16$. $[\mathrm{BMI}]+8.6 ; \mathrm{r}=-0.42 ; P<$ 0.001 ); in patients without DM B) insulin sensitivity $=-0.14$. $[\mathrm{BMI}]+8.6 ; \mathrm{r}=-0.39 ; P<$ 0.001 ) and with DM C) insulin sensitivity $=-0.12 \cdot[\mathrm{BMI}]+$ $6.5 ; \mathrm{r}=-0.37 ; P<0.001)$. BMI = body mass index; DM = diabetes mellitus

\section{a}

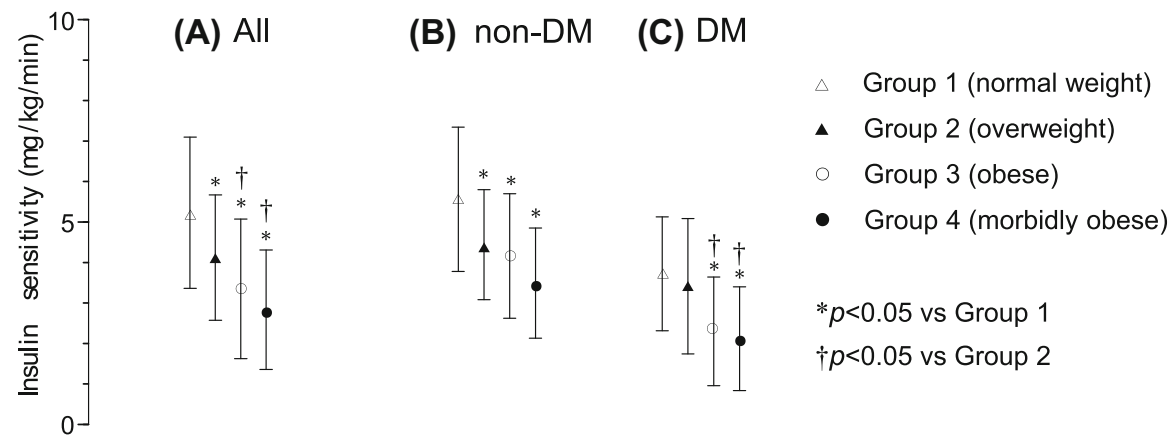

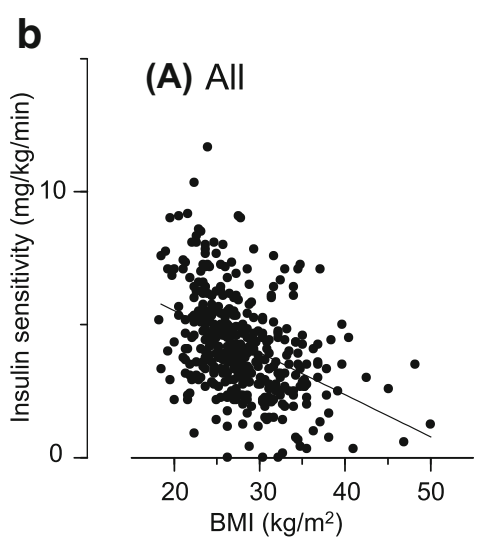

(B) non-DM

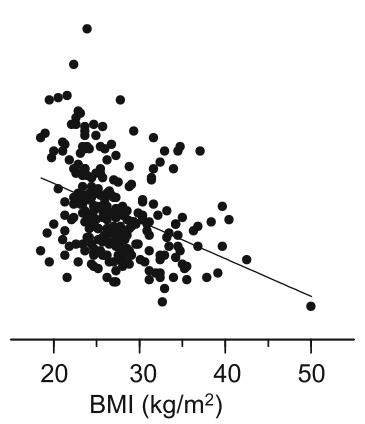

(C) DM

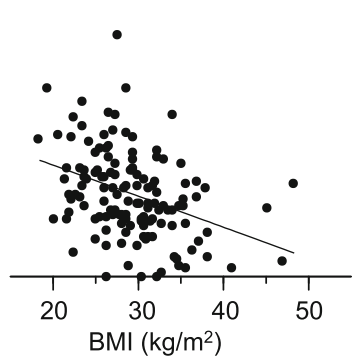

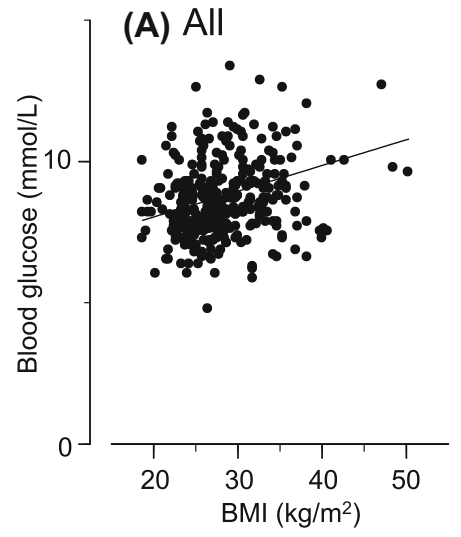

Fig. 3 Relationship between BMI $\left(\mathrm{kg} \cdot \mathrm{m}^{-2}\right)$ and average postoperative blood glucose concentration $\left(\mathrm{mMol} \cdot \mathrm{L}^{-1}\right)$ in all patients A) insulin sensitivity $=0.09 \cdot[\mathrm{BMI}]+6.2 ; \mathrm{r}=-0.30 ; P<$ 0.001 ); in patients without DM B) insulin sensitivity $=0.04 \cdot[\mathrm{BMI}]+$

The pathophysiologic mechanisms responsible for this "paradoxical" finding remain incompletely understood, particularly in the context of surgical tissue trauma. Several factors including enhanced metabolic reserves, stimulated production and release of protective cytokines, inhibition of the renin-angiotensin-aldosterone system, and augmented muscle mass in overweight subjects may have contributed. $^{34}$
(B) non-DM

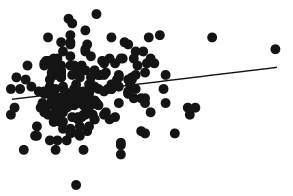

(C) DM
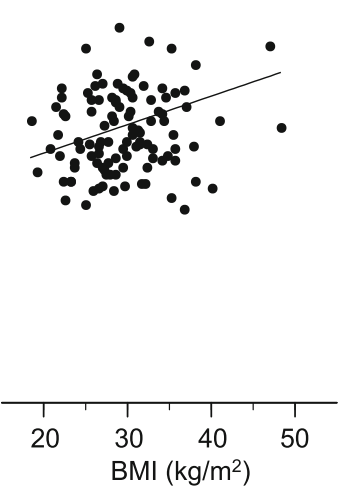

7.2; $\mathrm{r}=-0.16 ; P=0.02$ ) and with $\mathrm{DM} \mathrm{C}$ ) insulin sensitivity $=0.12$ $\cdot[\mathrm{BMI}]+6.4 ; \mathrm{r}=-0.34 ; P<0.001)$. BMI = body mass index; $\mathrm{DM}=$ diabetes mellitus

The endocrine and inflammatory alterations induced by cardiac surgery and CPB (i.e., augmented plasma concentrations of counterregulatory hormones and cytokines), together with the use of metabolically active drugs such as catecholamines, lead to a state of whole-body tissue insulin resistance and, as a result, hyperglycemia.

Because previous studies showed a significant link between the degree of insulin resistance and outcomes after 
Table 2 Outcomes

\begin{tabular}{|c|c|c|c|c|c|}
\hline & $\begin{array}{l}\text { Normal weight } \\
(n=111)\end{array}$ & $\begin{array}{l}\text { Overweight } \\
(n=158)\end{array}$ & $\begin{array}{l}\text { Obese } \\
(n=84)\end{array}$ & $\begin{array}{l}\text { Morbidly obese } \\
(n=34)\end{array}$ & $P$ value \\
\hline Major complication- $n(\%)$ & $11(10)$ & $15(10)$ & $9(11)$ & $6(18)$ & 0.56 \\
\hline Death- $n(\%)$ & $1(1)$ & $4(3)$ & $3(4)$ & $0(0)$ & 0.46 \\
\hline Myocardial failure- $n(\%)$ & $4(4)$ & $1(1)$ & $3(4)$ & $1(3)$ & 0.19 \\
\hline Stroke- $n(\%)$ & $1(1)$ & $0(0)$ & $1(1)$ & $0(0)$ & 0.56 \\
\hline Dialysis- $n(\%)$ & $2(2)$ & $3(2)$ & $3(4)$ & $1(3)$ & 0.83 \\
\hline Major infection- $n(\%)$ & $4(4)$ & $8(5)$ & $3(4)$ & $2(6)$ & 0.89 \\
\hline Sepsis- $n(\%)$ & $2(2)$ & $1(1)$ & $0(0)$ & $0(0)$ & 0.48 \\
\hline Pneumonia requiring ventilation- $n(\%)$ & $3(3)$ & $6(4)$ & $3(4)$ & $1(3)$ & 0.97 \\
\hline Deep sternal wound infection- $n(\%)$ & $1(1)$ & $2(1)$ & $0(0)$ & $1(3)$ & 0.53 \\
\hline \multicolumn{6}{|l|}{ Other complication } \\
\hline Minor infection- $n(\%)$ & $11(10)$ & $22(14)$ & $13(16)$ & $9(27)$ & 0.11 \\
\hline Pneumonia not requiring intubation- $n(\%)$ & $3(3)$ & $8(5)$ & $2(2)$ & $3(9)$ & 0.33 \\
\hline Superficial wound infection- $n(\%)$ & $5(5)$ & $5(3)$ & $5(6)$ & $6(18)$ & 0.01 \\
\hline Urinary tract infection- $n(\%)$ & $6(5)$ & $9(6)$ & $8(10)$ & $5(15)$ & 0.20 \\
\hline Transitional neurologic dysfunction- $n(\%)$ & $11(10)$ & $11(7)$ & $9(11)$ & $6(18)$ & 0.27 \\
\hline Atrial fibrillation- $n(\%)$ & $29(26)$ & $45(29)$ & $21(25)$ & $11(33)$ & 0.84 \\
\hline Average blood glucose in ICU-mMol L ${ }^{-1}$, mean (SD) & $8.3(1.3)$ & $8.7(1.4)$ & $9.1(1.5)$ & $9.7(3.7)$ & $<0.001$ \\
\hline Median blood glucose in ICU-mMol $\mathrm{L}^{-1}$, median [IQR] & $8.0[7.4-9.0]$ & $8.5[7.7-9.4]$ & $9.0[8.2-9.8]$ & $9.0[7.7-10.3]$ & $<0.001$ \\
\hline Peak creatinine-mMol $\cdot \mathrm{L}^{-1}$, median, $[\mathrm{IQR}]$ & 99 [84-130] & $107[94-138]$ & $110[90-133]$ & $117[90-174]$ & 0.10 \\
\hline Peak troponin-ng $\mathrm{dL}^{-1}$, median $[\mathrm{IQR}]$ & $4.3[2.3-7.7]$ & $4.1[2.5-8.4]$ & $3.7[2.2-7.6]$ & $6.6[2.2-9.7]$ & 0.49 \\
\hline Peak lactate-mMol $\mathrm{L}^{-1}$, median $[\mathrm{IQR}]$ & $2.4[1.8-3.4]$ & $2.4[1.8-3.2]$ & $2.3[1.6-3.7]$ & $2.5[2.0-3.2]$ & 0.85 \\
\hline Intubation time-hour, median [IQR] & $11[6-15]$ & $9[6-15]$ & $9[6-15]$ & $9[6-18]$ & 0.49 \\
\hline Length of ICU stay-hour, median [IQR] & $23[21-31]$ & $23[21-41]$ & $23[21-38]$ & $23[21-48]$ & 0.85 \\
\hline Length of hospital stay-day, median [IQR] & $8[6-11]$ & $8[6-10]$ & $8[6-10]$ & 9 [7-17] & 0.10 \\
\hline
\end{tabular}

One normal weight patient and one overweight patient had two major infections. Three normal weight patients, two obese patients, and three morbidly obese patients had two major infections, and one morbidly obese patient had three minor infections. Two normal weight patients, five overweight patients, one obese patient, and one morbidly obese patient had both one major and one minor infection

ICU = intensive care unit; IQR = interquartile range; $\mathrm{SD}=$ standard deviation

surgery, we speculated that altered insulin sensitivity may have contributed to the outcome discrepancies observed in different weight groups. ${ }^{35,36}$

Our demonstration of a linear negative relationship between the patients' BMI and intraoperative insulin sensitivity with increasing BMI, however, does not support this assumption.

Although morbidly obese patients in the present study had a numerically higher risk of infection, we did not find a statistically significant association between BMI and the incidence of postoperative complications. Further investigations are required to define the relationship among body weight, insulin sensitivity, and clinical outcomes in cardiac surgery. It also remains unclear if obese insulin-resistant patients clinically benefit from tighter glycemic control or any other intervention aimed at improving perioperative insulin sensitivity.
We acknowledge several limitations of this study. It was not powered to detect a true difference between weight groups in the incidence of secondary outcomes (i.e., postoperative complications). Assuming a 30-daymortality rate after cardiac surgery of $1.5 \%$ in normal weight, $1.0 \%$ in overweight, $0.9 \%$ in obese, and $1.2 \%$ in morbidly obese patients and corresponding major infection rates between 4 and 5\%, study populations of 96,000 and 15,000 patients would be needed to detect a $20 \%$ outcome difference with an alpha of 0.05 and a power of $0.8 .^{30,37}$

Although subjects not known for DM and presenting with blood glucose levels $>7.0 \mathrm{mMol} \cdot \mathrm{L}^{-1}\left(126 \mathrm{mg} \cdot \mathrm{dL}^{-1}\right)$ or $\mathrm{HbA}_{1 \mathrm{c}}>6.0 \%$ were not eligible, we cannot entirely exclude the possibility that some patients who were labelled "non-diabetic" actually had DM. 
Table 3 Odds ratios for major and infectious complications

\begin{tabular}{|c|c|c|c|c|c|c|c|}
\hline & \multirow[t]{2}{*}{$n$} & \multicolumn{2}{|c|}{ Major complications } & \multirow[t]{2}{*}{$P$ value } & \multirow[t]{2}{*}{ Adjusted OR } & \multirow[t]{2}{*}{$95 \% \mathrm{CI}$} & \multirow[t]{2}{*}{$P$ value } \\
\hline & & OR & $95 \% \mathrm{CI}$ & & & & \\
\hline Normal weight & 111 & 1 & & & 1 & & \\
\hline Overweight & 158 & 0.95 & 0.42 to 2.16 & 0.91 & 1.15 & 0.43 to 3.02 & 0.78 \\
\hline Obese & 84 & 1.09 & 0.43 to 2.77 & 0.86 & 0.57 & 0.16 to 2.00 & 0.38 \\
\hline \multirow[t]{3}{*}{ Morbidly obese } & 34 & 1.95 & 0.66 to 5.7 & 0.23 & 1.04 & 0.25 to 4.28 & 0.95 \\
\hline & \multirow[t]{2}{*}{$n$} & \multicolumn{2}{|c|}{ Infectious complications } & $P$ value & Adjusted OR & $95 \% \mathrm{CI}$ & $P$ value \\
\hline & & OR & $95 \% \mathrm{CI}$ & & & & \\
\hline Normal weight & 111 & 1 & & & 1 & & \\
\hline Overweight & 158 & 1.42 & 0.69 to 2.91 & 0.34 & 1.81 & 0.76 to 4.35 & 0.18 \\
\hline Obese & 84 & 1.64 & 0.73 to 3.67 & 0.23 & 1.80 & 0.60 to 5.4 & 0.29 \\
\hline Morbidly obese & 34 & 3.14 & 1.23 to 8.0 & 0.02 & 3.40 & 1.03 to 11.2 & 0.04 \\
\hline
\end{tabular}

Adjusted $\mathrm{OR}=\mathrm{OR}$ adjusted for age, gender, diabetes mellitus and $\mathrm{HbA1c} ; \mathrm{CI}=$ confidence interval; $\mathrm{OR}=$ odds ratio

\section{Conclusions}

Body mass index may be used as a simple predictor of insulin sensitivity during open heart surgery and as a predictor of the quality of postoperative glycemic control. A larger cohort will be necessary to evaluate the association of BMI, insulin resistance, and clinical outcomes in cardiac surgery.

Conflicts of interest All authors declare that they have no financial or non-financial interests that may be relevant to the submitted work.

Editorial responsibility This submission was handled by Dr. Hilary P. Grocott, Editor-in-Chief, Canadian Journal of Anesthesia.

Author contributions Hiroaki Sato and Thomas Schricker designed the study. Hiroaki Sato, Tamaki Sato, Takumi CodereMaruyama, and Thomas Schricker acquired data. Yosuke Nakadate, Hiroaki Sato, Tamaki Sato, and Thomas Schricker analyzed and interpreted the data. Yosuke Nakadate, Hiroaki Sato, and Thomas Schricker did statistical analysis. Yosuke Nakadate and Hiroaki Sato drafted the manuscript. All authors critically revised the manuscript and approved the final version.

Funding This research did not receive any specific grant from funding agencies in the public, commercial, or not-for-profit sectors.

\section{References}

1. Mukherjee B, Hossain CM, Mondal L, Paul P, Ghosh MK. Obesity and insulin resistance: an abridged molecular correlation. Lipid Insights 2013; 6: 1-11.

2. Ortiz VE, Kwo J. Obesity: physiologic changes and implications for preoperative management. BMC Anesthesiol 2015; 15: 97.

3. Huschak $G$, Busch T, Kaisers $U X$. Obesity in anesthesia and intensive care. Best Pract Res Clin Endocrinol Metab 2013; 27: 247-60.
4. Kuan P, Bernstein SB, Ellestad MH. Coronary artery bypass surgery morbidity. J Am Coll Cardiol 1984; 3: 1391-7.

5. Prasad US, Walker WS, Sang CT, Campanella C, Cameron EW. Influence of obesity on the early and long term results of surgery for coronary artery disease. Eur J Cardiothorac Surg 1991; 5: 6772 discussion 72-3.

6. Brandt $M$, Harder $K$, Walluscheck $K P$, et al. Severe obesity does not adversely affect perioperative mortality and morbidity in coronary artery bypass surgery. Eur J Cardiothorac Surg 2001; 19: 662-6.

7. Clough RA, Leavitt BJ, Morton JR, et al. The effect of comorbid illness on mortality outcomes in cardiac surgery. Arch Surg 2002; 137: 428-32 discussion 432-3.

8. Ludvik B, Nolan JJ, Baloga J, Sacks D, Olefsky J. Effect of obesity on insulin resistance in normal subjects and patients with NIDDM. Diabetes 1995; 44: 1121-5.

9. Unni US, Ramakrishnan $G$, Raj $T$, et al. Muscle mass and functional correlates of insulin sensitivity in lean young Indian men. Eur J Clin Nutr 2009; 63: 1206-12.

10. Hsu WC, Okeke E, Cheung S, et al. A cross-sectional characterization of insulin resistance by phenotype and insulin clamp in East Asian Americans with type 1 and type 2 diabetes. PLoS ONE 2011; 6: e28311.

11. Tewari N, Awad S, Macdonald IA, Lobo DN. Obesity-related insulin resistance: implications for the surgical patient. Int J Obes (Lond) 2015; 39: 1575-88.

12. Sato H, Carvalho $G$, Sato $T$, Lattermann $R$, Matsukawa $T$, Schricker T. The association of preoperative glycemic control, intraoperative insulin sensitivity, and outcomes after cardiac surgery. J Clin Endocrinol Metab 2010; 95: 4338-44.

13. Thiessen S, Vanhorebeek I, Van den Berghe G. Glycemic control and outcome related to cardiopulmonary bypass. Best Pract Res Clin Anaesthesiol 2015; 29: 177-87.

14. Leary AC, Stote RM, Breedt HJ, O’Brien J, Buckley B. Pharmacokinetics and pharmacodynamics of intranasal insulin administered to healthy subjects in escalating doses. Diabetes Technol Ther 2005; 7: 124-30.

15. Parsonnet $V$, Dean D, Bernstein AD. A method of uniform stratification of risk for evaluating the results of surgery in acquired adult heart disease. Circulation 1989; 79: I3-12.

16. Roques F, Nashef SA, Michel P, et al. Risk factors and outcome in European cardiac surgery: analysis of the EuroSCORE 
multinational database of 19030 patients. Eur J Cardiothorac Surg 1999; 15: 816-22 discussion 822-3.

17. Dobson G, Chong M, Chow L, et al. Guidelines to the practice of anesthesia - revised edition 2017. Can J Anesth 2017; 64: 65-91.

18. Monzillo LU, Hamdy $O$. Evaluation of insulin sensitivity in clinical practice and in research settings. Nutr Rev 2003; 61: 397412.

19. Holzinger U, Kitzberger R, Fuhrmann V, Funk GC, Madl C, Ratheiser $K$. Correlation of calculated indices of insulin resistance (QUICKI and HOMA) with the euglycaemic hyperinsulinaemic clamp technique for evaluating insulin resistance in critically ill patients. Eur J Anaesthesiol 2007; 24 : 966-70.

20. Caro JF. Clinical review 26: Insulin resistance in obese and nonobese man. J Clin Endocrinol Metab 1991; 73: 691-5.

21. Singer M, Deutschman CS, Seymour CW, et al. The third international consensus definitions for sepsis and septic shock (Sepsis-3). JAMA 2016; 315: 801-10.

22. Sjogren $J$, Malmsjo $M$, Gustafsson $R$, Ingemansson $R$. Poststernotomy mediastinitis: a review of conventional surgical treatments, vacuum-assisted closure therapy and presentation of the Lund University Hospital mediastinitis algorithm. Eur J Cardiothorac Surg 2006; 30: 898-905.

23. Rockx MA, Fox SA, Stitt $L W$, et al. Is obesity a predictor of mortality, morbidity and readmission after cardiac surgery? Can J Surg 2004; 47: 34-8.

24. Pan W, Hindler K, Lee VV, Vaughn WK, Collard CD. Obesity in diabetic patients undergoing coronary artery bypass graft surgery is associated with increased postoperative morbidity. Anesthesiology 2006; 104: 441-7.

25. Stamou SC, Nussbaum M, Stiegel RM, et al. Effect of body mass index on outcomes after cardiac surgery: is there an obesity paradox? Ann Thorac Surg 2011; 91: 42-7.

26. Phan K, Khuong JN, Xu J, Kanagaratnam A, Yan TD. Obesity and postoperative atrial fibrillation in patients undergoing cardiac surgery: systematic review and meta-analysis. Int J Cardiol 2016; 217: 49-57.

27. Najjar M, Yerebakan H, Sorabella RA, et al. Acute kidney injury following surgical aortic valve replacement. J Cardiac Surg 2015; 30: 631-9.

28. Schimmer C, Gross J, Ramm E, et al. Prevention of surgical site sternal infections in cardiac surgery: a two-centre prospective randomized controlled study. Eur J Cardiothorac Surg 2017; 51: 67-72.

29. Hysi I, Pinçon C, Guesnier L, et al. Results of elective cardiac surgery in patients with severe obesity (body mass index $\geq 35 \mathrm{~kg}$ / m2). Arch Cardiovasc Dis 2014; 107: 540-5.

30. Johnson AP, Parlow JL, Whitehead M, Xu J, Rohland S, Milne B. Body mass index, outcomes, and mortality following cardiac surgery in Ontario, Canada. J Am Heart Assoc 2015; 4: e002140.

31. Davenport DL, Xenos ES, Hosokawa P, Radford J, Henderson $W G$, Endean $E D$. The influence of body mass index obesity status on vascular surgery 30-day morbidity and mortality. J Vasc Surg 2009; 49(140-7): e1.

32. Mullen JT, Moorman DW, Davenport $D L$. The obesity paradox: body mass index and outcomes in patients undergoing nonbariatric general surgery. Ann Surg 2009; 250: 166-72.

33. Hainer $V$, Aldhoon-Hainerova I. Obesity paradox does exist. Diabetes Care 2013; 36(Suppl 2): S276-81.

34. Lavie CJ, Sharma A, Alpert MA, et al. Update on obesity and obesity paradox in heart failure. Prog Cardiovasc Dis 2016; 58: 393-400.

35. Thorell A, Nygren J, Ljungqvist $O$. Insulin resistance: a marker of surgical stress. Curr Opin Clin Nutr Metab Care 1999; 2: 69-78.

36. Ljungqvist $O$, Nygren J, Thorell A. Insulin resistance and elective surgery. Surgery 2000; 128: 757-60.

37. Gelijns AC, Moskowitz AJ, Acker MA, et al. Management practices and major infections after cardiac surgery. J Am Coll Cardiol 2014; 64: 372-81. 